\title{
BIRDS OF WARKWORTH CREEK, MANITOBA
}

\section{by Carroll D. Littlefield and Allan J. Pakulak}

Department of Fishery and Wildlife Biology, Colorado State University, Fort Collins, Colorado

A bird survey was conducted along Warkworth Creek (Figure 1) and its tributaries from June 11 through June 16, 1968, while we were doing research on Canada Geese (Branta canadensis) for the Manitoba Wildlife Branch, Department of Mines and Natural Resources. It was initiated near Chesnaye, Manitoba and proceeded northward for 52 miles to the Churchill River, 10 miles southwest of Churchill, Manitoba $\left(58^{\circ} 45^{\prime} \mathrm{N}, 94^{\circ}\right.$ $\left.05^{\prime} \mathrm{W}\right)$. To our knowledge this is the first ornithological investigation of this area, although several studies have been conducted in the immediate vicinity of Churchill during the past 40 years. The transect route was extremely remote and was accessible only by helicopter, canoe and/or walking.

The route transected five vegetative zones: (1) a sandy ridge; (2) open tundra with wooded creek bottoms; (3) mixed coniferous forest and tundra; (4) low coniferous forest; (5) tall coniferous forest. Vegetation on the sandy ridge included an overstory of black spruce (Picea mariana) and larch (Larix laricina) with an understory of Labrador tea (Ledum plaustre and L. groenlandicum), willows (Salix spp.) and several unidentified shrubs. Open tundra vegetation consisted predominantly of reindeer moss (Cladonia rangifernia and $C$. alpestris) with willow, larch, and black spruce occurring near lakes and creeks. Mixed tundra consisted of approximately one-half tundra and one-half coniferous forest with some trees reaching heights of 20 feet. Labrador tea was also abundant in these situations. Low coniferous forest ranged from 10 to 25 feet, while tall coniferous was 20 to 30 feet in height. These two types were interspersed with willow, sedge (Carex spp.), and hummock swamps. Nineteen miles were travelled in tall coniferous; 1 miles in open tundra; nine miles ir mixed coniferous and tundra; an eight miles in low coniferous. Th sandy ridge that was investigater consisted of approximately 2,50 acres surrounded by open tundra. I was located approximately eight mile east of Chesnaye. The abandoner Chesnaye Radar Site was near th northern extremity of the ridge.

On June 12 and 13 a few stream and lakes were still frozen at th southern extremity of the surves route in open tundra situations. Ter inches of snow fell on the evening of June 12 with temperatures remaining unseasonably cool through June 16 .

Following is an annotated check-list of the 73 species of birds observec along the route. Most birds appearec territorial and few migrants were noted.

ARCTIC LOON Gavia arctica Seven were observed on small ponds in open tundra, with no records from forested areas. One pair was heard calling from a small lake on the evening of June 11 near the Chesnaye Radar Site.

WHISTLING SWAN Olor colum bianus. On the afternoon of June 11 a single bird was seen flying from one small pond to another near the Chesnaye Radar Site. No nest was located, but nesting could have occurred. On July 22, two adults were seen on Fletcher Lake three miles from the original observation, which indicates a pair summered in the area.

CANADA GOOSE Branta canadensis. Commonly observed or heard throughout the survey. One hundred and fifty-nine geese were recorded, with the greatest densities occurring in low coniferous forest. Densities were also high on sandy ridges and open tundra. Individuals observed on open tundra were probably territorial 
birds from surrounding forested areas. One flooded nest and another with four eggs were recorded in low coniferous situations.

MALLARD Anas platyrhynchos. Most observations were from the Warkworth Lake area where 24 individuals were observed. Eight additional birds were observed north of Fletcher Lake on June 13.

BLACK DUCK Anas rubripes. The most commonly encountered dabbling duck. It was most often observed in coniferous forest.

PINTAIL Anas acuta. Common in all areas with highest densities occurring in open tundra situations. Two nests were located and one pair was observed copulating June 15 in Warkworth Creek, five miles south of Warkworth Lake.

GREEN - WINGED TEAL Anas carolinensis. Encountered principally in ponds near sandy ridges. On June 11, 12 were seen near Chesnaye Radar Site. Also seen regularly on the open tundra.

SHOVELER Spatula clypeata. One pair was observed in open tundra on June 12.

AMERICAN WIDGEON Mareca americana. Uncommon in wooded areas and absent elsewhere. The main concentration area was on Warkworth Creek near Warkworth Lake.

GREATER SCAUP Aythya marila. A few were seen in all areas, but they were much more numerous on Warkworth Creek and Warkworth Lake.

LESSER SCAUP Aythya affinis. Nine were recorded on Warkworth Lake on June 16.

COMMON GOLDENEYE Bucephala clangula. Some were seen along Warkworth Creek where the drainage system is bordered by coniferous forests. One female was observed June 12 on Fletcher Lake.

BUFFLEHEAD Bucephala albeola. A male and two females were recorded on Warkworth Creek, three miles south of Warkworth Lake on June 16. Apparently these observations represent the first Churchill area records.

OLDSQUAW Clangula hyemalis. Highest densities occurred in open tundra especially in the Pert and Fletcher lake areas where 22 adults were observed. It was less common in coniferous forest.

WHITE-WINGED SCOTER Melanitta deglandi. Two pairs were observed on a small lake near the Chesnaye Radar Site on June 11.

COMMON SCOTER Oidemia nigra. Ten individuals (four pairs, two singles) were seen in the vicinity of the Chesnaye Radar Site and the open tundra east of the site.

RED - BREASTED MERGANSER Mergus serrator. We observed one pair in the open tundra east of Chesnaye Radar Site and four additional birds near Warkworth Lake.

GOSHAWK Accipiter gentilis. A lone hunting bird was observed flying along Warkworth Creek, four miles south of Warkworth Lake on June 15.

ROUGH - LEGGED HAWK Buteo lagopus. We encountered this species regularly over the open tundra, but rarely elsewhere. Six individuals including one melanistic form were observed June 12 and 13 over the tundra.

MARSH HAWK Circus cyaneus. Eight were seen during the survey with four of these occurring over the open tundra.

OSPREY Pandion haliaetus. Two adult birds were seen perched and flying along the western edge of Warkworth Lake June 16.

SPARROW HAWK Falco sparverius. A single male was observed June 11 at the Chesnaye Radar Site.

SPRUCE GROUSE Canachites canadensis. On June 16 a male was recorded three miles south of Warkworth Lake.

WILLOW PTARMIGAN Lagopus lagopus. Most common on sandy ridges and open tundra. Twenty-three were seen with 22 located in these two areas. A nest with 10 eggs was located June 11 near Chesnaye Radar Site.

SEMIPALMATED PLOVER Charadrius semipalmatus. Common where exposed gravel occurred. A nest with four eggs was examined in an abandoned gravel pit near Chesnaye Radar Site on June 11. Three other pairs 
were on territory in the same area.

AMERICAN GOLDEN PLOVER Pluvialis dominica. Observed only in open tundra situations east and northeast of the Chesnaye Radar Site.

COMMON SNIPE Capella gallinago. Abundant in coniferous forested areas, but not recorded on the tundra. Thirty-three were seen or heard on the survey.

WHIMBREL Numenius phaeopus. Occurred only in open and mixed tundra situations. One pair was observed pursuing jaegers on June 12, so nesting probably was occurring.

LESSER YELLOWLEGS Totanus flavipes. Few were seen in open tundra, but they were abundant in coniferous forest interspersed with swamps.

LEAST SANDPIPER Erolia minutilla. Absent in all areas except open tundra where four were seen and mixed tundra where a single pair was observed.

DUNLIN Erolia alpina. Most often encountered in open tundra. The species was not seen in wooded areas.

SHORT - BILLED DOWITCHER Limnodromus griseus. A single bird was seen in open tundra but the major concentration was in wooded areas, interspersed with meadows.

STILT SANDPIPER Micropalama himantopus. Most abundant in open tundra habitat, although it was observed in all habitat types.

SEMIPALMATED SANDPIPER Ereunetes pusillus. Seven were recorded near the Chesnaye Radar Site June 11.

HUDSONIAN GODWIT Limosa haemastica. Three pairs were seen in open and mixed tundra habitats. All observations were made in areas where few trees occurred.

NORTHERN PHALAROPE Lobipes lobatus. Observed regularly on ponds in all areas, but most abundant in open tundra.

PARASITIC JAEGER Stercorarius parasiticus. Four were observed hunting over open tundra June 12 and 13.

LONG-TAILED JAEGER Stercorarius longicaudis. Two were seen
June 13 in open tundra and three were seen flying northwest over mixed tundra June 14.

HERRING GULL Larus argentatus. One nest with three eggs was located near Fletcher Lake. Commonly seen around lakes in open tundra and in the area around Warkworth Lake.

B O N A P A R E'S GULL Larus philadelphia. Common near the sandy ridge. Other observations consisted of individuals flying over open tundra and another diving at the observers in a mixed tundra situation.

ARCTIC TERN Sterna paradisaea. Commonly seen over open tundra and coniferous habitat that was interspersed with small lakes and swamps.

SHORT-EARED OWL Asio flam. meus. Four were observed near Chesnaye Radar Site June 11. These were the only individuals observed during the survey.

YELLOW - SHAFTED FLICKER Colaptes auratus. A dead bird was found at the Chesnaye Radar Site June 11, and another individual was seen three miles south of Warkworth Lake June 16.

OLIVE-SIDED F L Y C A T C HER Nuttallornis borealis. A singing individual was observed June 15, four miles south of Warkworth Lake.

HORNED LARK Eremophila alpestris. Only observed June 11 on the sandy ridge near the Chesnaye Radar Site.

TRE E S W L LOW Iridoprocne bicolor. Three were recorded. All appeared to be migrating.

GRAY JAY Perisoreus canadensis. Confined to coniferous forests. Most were associated with short coniferous forest.

COMMON RAVEN Corvus corax. Regularly seen in all habitats.

ROBIN Turdus migratorius. Seven were observed on a sandy ridge near the Chesnaye Radar Site June 11. No observations occurred in other zones.

GRAY-CHEEKED THRUSH Hylocichla minima. Abundant in coniferous forest. Twenty-six birds were seen on the survey with 21 sightings in short and tall coniferous forest. 


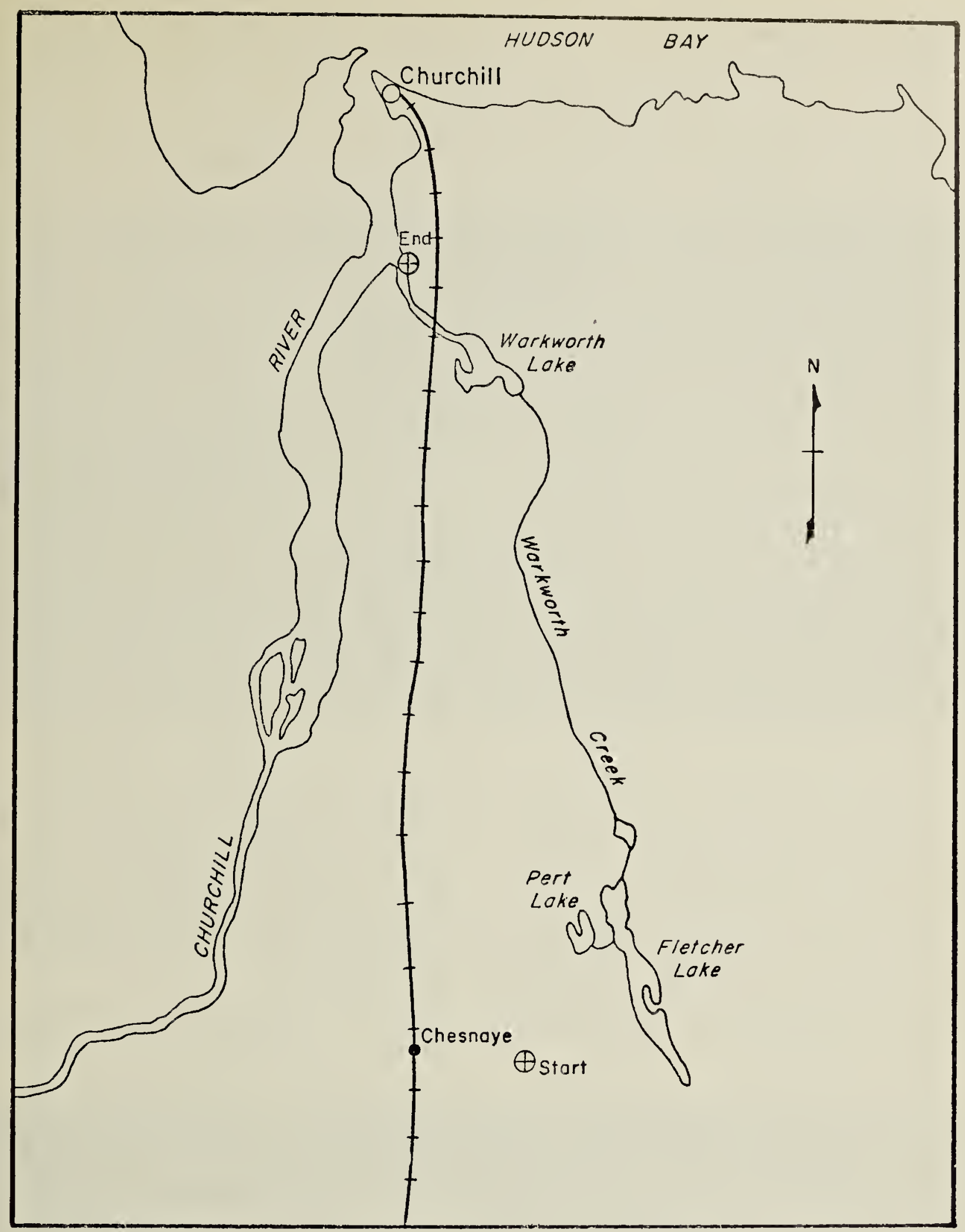

Figure 1. Map of Warkworth Creek area, northern Manitoba.

R U B Y - C R O W N E D KINGLET Regulus calendula. Three individuals were observed along Warkworth Creek in both short and tall coniferous forest.

BOHEMIAN WAXWING Bombycilla garrulus. Common in both short and tall coniferous forest. Twenty-two individuals were seen in these habitats.
YELLOW WARBLER Dendroica petechia. Uncommon in the willows along Warkworth Creek near Warkworth Lake; four individuals were seen.

MYRTLE WARBLER Dendroica coronata. Sightings were in association with coniferous forest habitats. Two were seen near Chesnaye Radar Site and two additional birds were 
observed in tall coniferous along Warkworth Creek.

B LACK P OLL WARBLER Dendroica striata. This species was the warbler most often noted during the survey, with regular sightings in coniferous forests. Twelve individual birds were seen or heard.

Y ELLOWTHROAT Geothlypis trichas. A male was heard in a willow swamp June 14 approximately 20 miles south-southeast of Warkworth Lake.

WILSON'S WARBLER Wilsonia pusilla. On June 14 a single male was observed in mixed tundra among thick willows approximately 22 miles southeast of Warkworth Lake.

RUSTY BLACKBIRD Euphagus carolinus. Common in all situations except open and mixed tundra.

PINE GROSBEAK Pinicola enucleator. Regularly encountered in both short and tall coniferous forests.

HOARY REDPOLL A canthis hornemanni. Six individuals were observed near Chesnaye Radar Site and two were seen in small willows in open tundra east of the radar site.

COMMON REDPOLL A canthis flammea. Observed in all areas with the major concentration occurring around the sandy ridge. One pair was observed carrying nest material in open tundra June 12.

WHITE-WINGED CR O S BILL Loxia leucoptera. A courting pair was observed two miles south of Warkworth Lake June 16. This record represents one of the few sightings of this species in the Churchill area.

SAVANNAH SPARROW Passerculus sandwichensis. Common to abundant along the entire survey route. They appeared more common among willows on open tundra.

SLATE-COLORED JUNCO Junco hyemalis. We observed the species in both short and tall coniferous forest near Warkworth Lake.

TREE SPARROW Spizella arborea. The most abundant sparrow observed on the survey. A total of 132 individuals were observed, but the species was rare in tall coniferous forest.
HARRIS' SPARROW Zonotrichia querula. Common in all areas except tall coniferous forest. Abundant in short coniferous and mixed tundra areas.

W H I T E - CROWNED SPARROW Zonotrichia leucophrys. Abundant on sandy ridges but less common in other areas especially in tall coniferous habitat.

WHITE - THROATED SPARROW Zonotrichia albicollis. A single singing individual was observed at Chesnaye Radar Site June 11.

FOX SPARROW Passerella iliaca. Common on sandy ridges around the Chesnaye Radar Site and surrounding creek bottoms in open tundra.

LINCOLN'S SPARROW Melospiza lincolnii. Three individuals were observed in forested areas along the survey route.

LAPLAND LONGSPUR Calcarius lapponicus. Common in open tundra habitat, and only occasionally observed on the sandy ridge and in mixed tundra.

SMITH'S LONGSPUR Calcarius pictus. Eight were seen on the sandy ridge near the Chesnaye Radar Site. No other individuals of this species were observed.

SNOW BUNTING Plectrophenax nivalis. A single bird was observed near Fletcher Lake June 12.

\section{REQUEST FOR INFORMATION RE: BALD EAGLES}

A study is being conducted to determine the migration routes of Bald Eagles breeding in Minnesota and Bald Eagles wintering in South Dakota. Both immature and mature birds have been color-marked yellow, green, turquoise, or in combination. Information desired: color and portion of wing or tail that is marked, date of sighting, location, and activity of the bird. Exact time of sighting and name of person making the observation is also necessary. Send information to: Thomas C. Dunstan, Dept. of Biology, Univ. of South Dakota, Vermillion, South Dakota 57069. 